\title{
Buite-aardse rasionaliteit: Uitvlug in fantasie of grootste uitdaging ooit aan filosofie en teologie?
}

A J Antonites

Universiteit van Pretoria

\begin{abstract}
Extra terrestrial intelligence: Escape in fantasy or greatest challenge to philosophy and theology ever?

The concept of extra-terrestrial intelligence was first mooted by philosophers like Aristotle and Lucretius as well as natural scientists like Huygens and Whewell. It is considered whether UFO reports rather than indicating something real provide a symptom of the current religious cultural situation in Europe. Should rational life elsewhere in the universe be real, it is argued that biological life would be a neccessary condition. The divergence and convergence hypotheses are examined. The fundamental prerequisite is the existence of other solar systems with planets other than our own. Insights from biology and astronomy are placed in the context of philosophical discourse.
\end{abstract}

\section{INLEIDING EN PROBLEEMSTELLING}

Enkele jare gelede het vliegtuie begin om chemikalieë op wolke te strooi, om sodoende reën te veroorsaak. Sonder om te oordeel oor die effektiwiteit daarvan, het dit hewige reaksie ontlok. Dit was veral 'n teologiese probleem: 'Word hier nie gepeuter met God se skepping en wil nie'? Nie net die verkenning van die buitenste ruimtes deur ruimtevaart nie, maar die hedendaagse moontlikheid dat rasionele lewe buiten die van die mens bestaan en wat moontlik meer gevorderd in wetenskap en tegnologie as die van die mens is, is ' $n$ veel groter teologiese en filosofiese probleem. Probleme sowel as insigte in hierdie verband kan egter nie onder die mat gevee word nie. Dit gebeur dikwels in die wetenskap dat 'n nuwe insig of teorie aanvanklik geen aandag trek nie of as absurd beskou word, maar dan mettertyd bruikbaar begin word. 'n Goeie voorbeeld hiervan is Mendel se genetika of die kwantum-teorie. Die moontlikheid van swart gate (black holes) in die heelal is aanvanklik beskou as te ongelooflik en 'n bespreking daarvan in wetenskaplike kringe" 'onfatsoenlik'. 'Space travel, or even the sending of instrumental probes, to other solar systems is so far beyond our reach that it is not worth while discussing it at a sober philosophical cocktail party' (Beck 1987:9). 
Dit alles is deel van die konteks van die probleem van die tema: die algehele vreemdheid en nuutheid daarvan en die respons daarop. Indien buite-aardse rasionaliteit iets te sê het vir filosofie en teologie is dit nodig om vas te stel of dit meer behels as wat voorkom in wetenskapsfiksie en/of wetenskapsfantasie ${ }^{1}$. Is die bestaan daarvan 'n wetenskaplike moontlikheid? Daar sal dus eers aangetoon moet word waarom dit meer as fiksie is. Daar is egter 'n logiese voorwaarde: alvorens bogenoemde gedoen kan word, moet die bestaan van ander sonnestelsels buite ons eie eweneens aangetoon kan word. Die filosoof en teoloog kan dit egter nie self navors nie, en maak gebruik van die insigte van ander wetenskappe soos die sterrekunde (astronomie) en biologie. Die wetenskapsfilosoof plaas hierdie insigte dan in ' $n$ filosofiese argument om so by ' $n$ gevolgtrekking uit te kom. Vervolgens plaas hy dit ook in sy wyer filosofiese verwysingsraamwerk. Eers daarna kan bepaalde filosofiese en teologiese implikasies verreken word.

\section{AGTERGROND VAN DIE PROBLEEM}

Dit was filosowe wat die eerste keer die aangeleentheid van buite-aardse rasionaliteit aan die orde gestel het. Aristoteles was oortuig dat buite-aardse rasionele wesens bestaan. Lucretius (89-55 v C) was die eerste persoon wat sistematies daaraan aandag gegee het. Kort daarna het Plutarchus $(100 \mathrm{n}$ C) gestel dat die aarde geen bevoorregte posisie in die heelal het nie en so Aristoteles se beskouing gevolg. Lucretius het ook gemeen dat die menslike wêreld nie uniek is nie. Ruimte is oneindig en oral tref mensversamelings van materie aan. Sommige hiervan is wêrelde met hulle eie lug (atmosfere), mensesoorte en dieresoorte. Laasgenoemde twee het op natuurlike manier ontstaan en het uiteenlopende natuurlike seleksie ondergaan in verskillende soorte van omgewings. So het uiteenlopende beskouings ontwikkel. Daar is geen plan of ontwerp in die heelal nie en hemelliggame bestaan nie ter wille van hulle inwoners nie. Almal bestaan toevallig. Daar bestaan ontelbare wêrelde in wisselende grade van ooreenkoms en verskil. Gevolglik het Lucretius gemeen dat daar ander wêrelde met inwoners moet wees, waarvan sommige meer soos ons is en ander weer anders (De rerum naturae, II, V). Moderne en hedendaagse wetenskappe neem in beginsel tot ' $n$ hoë mate dieselfde gedagtes van Lucretius weer op.

Ander filosowe wat buite-aardse rasionaliteit eksplisiet moontlik geag het, was Nicolas Cusanus en veral Giordano Bruno en Campanella in die Renaissance. Later het John Locke, Lambert en Immanuel Kant hierby aangesluit. Natuurwetenskaplikes soos Gassendi, Christian Huygens en William Whewell het ook buite-aardse rasionele lewe as realiteit beskou. 
Die kerkvader Augustinus het hom egter teen 'n veelheid van wêrelde uitgespreek. In die Renaissance het die kerk die uitdaging - naamlik dat 'n veelheid van wêrelde met inwoners daarop bestaan - baie vinnig aanvaar: die brandstapel vir Giordano Bruno!

Vir eeue hierna is omtrent geen aandag aan die saak gegee nie. 'n Opflikkering kom teen die einde van die 19de eeu wanneer die Italiaanse sterrekundige Schiaparelli verklaar dat hy kunsmatige kanale op Mars waargeneem het. Dit het sensasie oor inwoners op Mars laat ontstaan. 'n Ander sterrekundige, E M Antoniadi, het egter later aangetoon dat die kanale ' $n$ vergissing was ${ }^{2}$. Wetenskapsfiksie het egter ondanks Antoniadi begin om te verskyn oor ander planeetwesens. Dis waarskynlik die herkoms van die uitdrukking 'groen marsmannetjies'!

Kort na die Tweede Wêreldoorlog, vanaf 1947, is groot getalle 'vreemde vlieënde voorwerpe' (UFO's) waargeneem. 'n Debat het begin oor die egtheid hiervan. Wetenskapsfiksie in boeke en films het dramaties toegeneem. In die Verenigde State van Amerika het die staat, en veral die weermag, waarnemings deurgaans afgemaak as bedrog of ander oorsake daarvoor gesoek. Ondersoeke het ook getoon dat talle waarnemings in werklikheid lugbalonne, vliegtuie, metereologiese effekte en soms massas vuurvliegies was. Hallusinasies is soms ook as oorsake genoem. 'n Aansienlike persentasie waarnemings kon egter nooit op dergelike wyse weg verklaar word nie. Die indruk is geskep dat die staat en weermag algehele swye gehandhaaf het, naas die afwysende verklarings. Enersyds is dit ook wetenskaplik sinvol om eers nie-vreemde verklarings te soek - wat Thomas Kuhn sou noem roetine of normale wetenskap. In baie gevalle was dit ook geslaagd (kyk later Paaseilande en Nazca-strepe in Peru). Andersyds slaag dit beslis nie, byvoorbeeld die voorkoms van diagramme en sirkels in graanlande oor dic wêreld. Dieselfde geld vir die konsistensie van genoemde aansienlike persentasie waarnemings.

Die vraag kan inderdaad gevra word of die aandag gee aan en soeke na buiteaardse rasionele wesens nie ' $n$ simptoom is van die godsdienstige, kulturele, sosiale en psigologiese situasie by die waarnemers self nie. By 'n groot persentasie van die Westerse mens in Europa het godsdienstige ankers van die Joods-Christelike geloof weggeval.

Indien opnames as betroubaar beskou kan word, is daar tans 'n geringe persentasie in Europa wat eredienste bywoon en gelowig is. Victor Frankl meen tereg dat dit eie aan die mens is om sinstrewend te wees: hy wil in iemand of iets glo, anders verloor hy sin. Mense soek soms krampagtig na iets om in te glo. Meer as een navorser het verwys na die identiteitskrisis van die Europese mens, naamlik dat hy na die Tweede Wêreldoorlog begin het om alle waardestelsels te betwyfel en so lewensrigting verloor het. Hy het dus in 'n krisis beland waartydens spanningsituasies ontstaan het. 
Bring die verskyning van buite-aardse wesens nie 'n mate van verligting in die spanning nie? Nog meer: bied dit nịe nuwe ankers, en wel as 'n substituut, vir Christelike waardes nie?

Korrelleer die waarnemings van vreemde vlieënde voorwerpe (VVV) nie juis met tye van smeltkroes en krisis nie? Naas VVV is daar ook 'n toename in beweerde verskynings van engele en die paranormale. Daar is ' $n$ toename in programme oor VVV en kommentators beweer '... hulle is heel ernstig hoor' (Caproro .1995)! Mense kan skynbaar met dolfyne 'praat' deur net aan die 'mistieke' diere te raak, en ook so fisies of geestelik genees word.

Hieromtrent kan enersyds opgemerk word dat krisistye wel 'n sterker bewuswording van vreemde verskynings te weeg mag bring. Dit kan ook geredelik aanvaar word dat enkele mense sin en heilsbetekenis hierin mag soek en dat dit inderdaad by individue ook gebeur. Teologies gesproke sou dit nie die eerste keer wees dat mense heil wil vind in geskape objekte of wesens nie. Andersyds raak sodanige response logies gesproke egter nie noodwendig die ontologiese posisie en werklikheidsgehalte van engele of VVV nie. Die meeste VVV-waarnemings vind plaas in die Verenigde State van Amerika waar daar ' $n$ heel ander situasie as Europa bestaan met betrekking tot genoemde ankers. Met betrekking tot die mitologisering van die dolfyne: ondanks die mitologisering het onlangse navorsing verassende insigte na vore gebring, onder andere dat die dolfyn hoogs intelligent en nie bloot net instinkmatig gedrewe is nie. Voortgaande navorsing het verder getoon dat die dolfyn inderdaad ' $n$ besondere dier is.

Dis ook eie aan die mens om by die eerste konfrontasie met 'n verskynsel of objek wat geheel nuut of vreemd is, dit of te ontken of iets sinistêrs daarin te lees. Die mens koester geen passie vir dinge waarvan hy nie bewus is nie. Die geskiedenis van die wetenskap (en nie net dié van die kerk nie!) bied aan die mens rede tot nederigheid: Galileo Galilei se nuwe siening dat die maan nie volmaak rond is nie en dat Jupiter mane het, was deur die Rooms Katolieke Kerk as 'onsin' en 'uiters gevaarlik' uitgewys. Galileo se uitnodiging om deur die toe pas uitgevinde teleskoop te kom kyk, is begroet met 'duiwelsapparate' en 'duiwelskunste'! Nadat Johannes Kepler ('n Protestant) kort hierna ook die heliosentriese teorie op sy manier onderskryf het, het die Lutheraanse kerk die heliosentriese teorie amptelik as 'kettery' verklaar. Die hedendaagse oorhaastige koppeling van VVV verskynsels en die soeke na buite-aardse rasionele lewe met die 'okkulte', of met Satanisme, lyk sterk na 'n parallel.

Dit is ook korrek dat die hedendaagse New Age-lewensopvatting 'n pro-benadering het ten opsigte van VVV, asook ten opsigte van bewussyn en bewussynsverandering. Die eerste vlaag VVV-verskynsels en die belangstelling daarin het egter plaasgevind lank voor die koms van die hedendaagse New Age-lewensopvatting. Veel eerder lyk dit of: 
* die New Age vanuit sy waardestelsel 'n verandering — wat ongeag en onafhanklik van enige godsdiens of lewensopvatting plaasgevind het - raakgesien en geïnterpreteer het, en

* die New Age die Christendom hierin voorgespring het met sy aandag daaraan. (Dit geld ook vir die ekologie.)

Die afgelope ses dekades het dit dikwels gebeur dat talle inhoude van die wetenskapsfiksie mettertyd 'n wetenskaplike weerklank of selfs uitkoms gehad het of wetenskaplike ontwikkeling sterk gë̈nspireer het. Sou die proliferasie van wetenskapsfiksie oor buite-aardse wesens en ruimtetuie nie ook dieselfde ontwikkeling kan toon nie? Talle wetenskapsfiksie-inhoude het inderdaad reeds gerealiseer, soos hedendaagse ruimtevaart, verkenning van planete en die beoogde bou van ruimtestasies. Tog kan mens nie logies hiervan sondermeer 'n algemene reël maak nie: nie enige wetenskapsfiksie word wetenskap nie!

As daar tot sover nog geen beslissende getuienis is van lewe buite die aarde en ander sonnestelsels is nie, sou mens dan nie kan konkludeer dat dit inderdaad ook nie bestaan nie en dat dit maar net wetenskapsfiksie is? Hierdie argument wat dikwels voorkom lyk op die oog af na 'n grondige argument. In werklikheid is dit 'n drogargument en wel 'n argumentum ad ignorantiam: nie-wete of onkunde oor 'n saak bied geen premisse vir die ontkenning van 'n saak nie. Die omgekeerde geld natuurlik ook.

Dit is juis dit wat die hooflyn-argumentering van hierdie artikel wil aandui: is hier slegs ' $n$ nie-wete en wetenskapsfiksie? Ek wil argumenteer dat hierdie aangeleentheid beweeg het weg van die nie-weet en fiksie-situasie na 'n wetenskapgegronde situasie, en dat dit daarom sowel deur die filosofie as teologie vroegtydig ernstig opgeneem behoort te word.

\section{BUITE-AARDSE BIOLOGIESE LEWE AS 'N NOODSAAKLIKE VOOR- WAARDE VIR RASIONELE BUITE-AARDSE LEWE}

\subsection{Buite-aardse biologiese herkoms?}

In die biologiese wetenskappe geld die evolusie-teorie vandag as 'n goed bevestigde paradigma, al is dit redelik gewysig sedert Charles Darwin se Origin of species. Die oorgang van anorganiese fisiese chemiese molekules na biologiese lewe by die oerbegin was vir talle dekades ' $n$ moeilike probleem. Biochemici Keete, G Newton en S Miller meen egter dat hulle ' $n$ oplossing gevind het: drie eenvoudige organiese molekules wat 
na bewering volop in die 'oersop' (naamlik Pantoyl lactone, Bralanien en Cysteamien) is, sou volgens hulle saamsluit om 'n molekuul naamlik Panteteïn te vorm op voorwaarde dat dit teen $40^{\circ} \mathrm{C}$ verhit sou word. So 'n temperatuur sou algemeen op aarde voorgekom het (Aldhous 1994).

Hoewel so 'n moontlikheid nie uitgesluit is nie, meen talle wetenskaplikes dat spesifieke seleksie waar anorganiese materie in oeroseane in beginsel sou kon kombineer tot ' $n$ geweldige getal van aminosure (en dit binne 'n paar honderd miljoen jaar na die vorming van die aarde en dat dit so sou kon kom tot voortplantende organismes), uiters skraal is. Wel sou anorganiese materie in oeroseane in beginsel kon kombineer tot 'n enorme getal van aminosure (noodsaaklike boustene vir lewe), maar slegs twintig speel ' $n$ bepalende rol in biologiese evolusie.

'n Debat het onder bioloë ontstaan of die aminosure chemies uitsluitlik op aarde ontstaan het 'en of dit nie eerder 'n buite-aardse oorsprong gehad het wat op die aarde beland het. Laasgenoemde hipotese figureer deesdae al hoe sterker. Die oortuiging bestaan dat biologiese lewe wydverspreid voorkom in die heelal en dat die Darwinistiese teorie gevolglik onvolledig is. Aardse lewe het ' $n$ koolstof- en waterbasis. Koolstof is verder ' $n$ uitstekende molekulêre verbinder. Sy besondere atoomeienskappe maak die ontstaan van molekulêre stringe soos DNA moontlik. Sonder 'n wyse van stoor en oordrag van groot hoeveelhede informasie (wat nodig is vir die ontwikkeling van 'n lewende organisme) sou biologiese lewe nie moontlik wees nie. Koolstof en waterstofatome is die beste kandidate hiervoor.

Andere soos Feinberg en Shapiro meen weer dat ons aardse vorm van DNA-gebaseerde lewe eerder 'n besondere geval van iets meer algemeen is: koolstof en water hoef nie noodwendig noodsaaklike bestanddele van lewe te wees nie. Gegewe radikaal ander toestande elders in die heelal, sou chemiese reaksies en molekulêre kombinasies wat skaars of afwesig is op aarde, die noodsaaklike vorme van organismes kan produseer. In lae temperature sou lewe byvoorbeeld kan floreer in vloeistowwe soos ammoniak of sekere soorte olies. Stringe van waterstofatome wat op aarde plofbaar sou wees, sou hier stabiel genoeg kan wees om die lang molekulêre stringe van informasie te vorm, as 'n analogie van DNA. Net so sou 'n silikaatgebaseerde lewe kon ontstaan in 'n omgewing met hoë temperature, maar wat 'n koolstof gebaseerde lewe weer onmoontlik sou maak. Hierdie bioloë meen dus dat alternatiewe chemiese kombinasies ook basisse vir die ontstaan van lewe elders kan wees (kyk Fine 1988:268).

Andere soos professor C Sagan meen ook dat lewe dwarsdeur die heelal voorkom, maar dat dit baie ooreenstem met die op aarde. Lewe benodig 'n oplosmiddel, een of ander vloeibare medium sodat energie-reaksies kan plaasvind. Water wat bestaan uit waterstof is die element wat die meeste in die heelal voorkom. Dit is nie net 'n uitstekende oplosmiddel nie, maar kan volgens bioloë 'n vloeistof bly binne 'n betreklik 
groot reeks van temperature. Sagan stel dat koolstofwater universeel in die heelal is, en dat ' $n$ redelike persoon geen ander alternatief het as om vas van oortuiging te wees dat lewe elders bestaan, en dat dit dieselfde fundamentele basis het as lewe op aarde nie (Pine 1989:268). Sou Sagan reg wees bied dit rugsteun vir die konvergensie hipotese.

Die bioloë moet oor hierdie saak beslis. Wat ons wel hieruit as belangrik kan aflei, is dat 'n groot getal (indien nie verreweg die meeste) wetenskaplikes wel op een of ander wyse die realiteit van ten minste biologiese lewe elders aanvaar. Die bestaan van komplekse organiese molekules elders in die heelal (ook by tussen-ster newels) is tewens nie eers meer 'n kontensieuse aangeleentheid nie (kyk Hoyle \& Wickramasinge 1992:105). Prof D M Raup van die Departement Geofisiese Wetenskappe aan die Universiteit van Chicago formuleer dit so: 'There now seems to be a reasonable consensus among biologists and biochemists that the spontaneous origin of life is fairly straightforward chemically and hence that primitive life, at least, in other planetary systems is possible and even quite probable' (Raup 1987:32).

'n Hele aantal bioloë toon verder aan dat organiese komponente in meteoriete voorkom (Raup 1987:32; Hoyle \& Wickramasinge 1992:109). Hierbenewens redeneer talle sterrekundiges en bioloë dat daar onbetwisbare evidensie is dat kosmiese biologiese lewe miljoene jare gelede (dus van buite die aarde) ekstern bygevoeg is by die aarde in die vorm bakterieë en virusse. Die fossiel-rekord van $\mathbf{5 7 0}$ miljoen jaar gelede toon die voorkoms op aarde van volledige entiteite soos bye, krewels, eendagsvlieë, kokkerotte en naaldekokers wat in terme van evolusie geen voorgeslag-vertakking het in die fossiel-rekord nie. Dis veral stof van komete wat bakterieë en virusse in die aarde se atmosfeer gedeponeer het, waarna reën dit na die aarde gebring het. Hulle sien 'n korrelasie (nou nog) tussen die voorkoms van kwale soos longontsteking en kinkhoes met die aarde se beweeg vir kort periodes deur bane van komete (Hoyle \& Wickramasinghe 1992:112). Kosmiese mikrobiologiese aktiwiteit is dus reeds vir miljoene jare aan die gang.

Meeste bioloë het aanvanklik so 'n siening verwerp en dit glad nie eers ernstig opgeneem nie. In Junie 1994 het 'n groep navorsers onder leiding van prof L Snyder van die Universiteit van Illinois te Urbana Champaign egter aangekondig dat hulle aminosuur-glisien ontdek het in die inter-ster newel Saggitarius $B$ (geleë in die middelpunt van ons galaktika (melkweg). Volgens bioloë is dit 'n belangrike bousteen van biologiese lewe.

In dieselfde maand en jaar maak 'n Anglo-Franse chemiese wetenskaplike span bekend dat die reaksies wat lei tot die vorming van komplekse molekules soos aminosure, baie vinniger kan plaasvind as wat heersende teorie tot dusver gemeen het. Reaksies vind selfs vinniger plaas by lae temperature as wanneer dit warmer is (Baggot 1994). 
Dit alles is nog nie finale getuienis vir die bestaan van biologiese lewe elders nie. Dit is egter wel baie duidelik dat die moontlikheid nou nie net baie groter as voorheen is nie, maar dat dit as noodsaaklike voorwaarde reeds sterk wetenskaplike rugsteun het. 'n Definitiewe beweging weg van wetenskapsfiksie het dus gerealiseer wat aan wetenskaplikes voldoende grond bied om nou verder te soek na bevestiging, en wel as genoegsame voorwaarde. Die eerste poging was die twee onbemande Viking ruimtetuie, wat in 1975 op Mars geland het en grond op die oppervlakte opgeskep het, dit chemies en biologies ontleed het, en resultate na die aarde versend het. Die uitslag was 50\%-50\% ten opsigte van biologiese lewe elders, dit wil sê onbeslis. Binnekort vertrek 'n VSA-ruimtetuig as deel van die 3.2 biljoen dollar Cassinni-projek na Titan ${ }^{3}$, die reuse maan van Saturnus. Dit bevat 'n landingvaartuig, die Christian Huygens, wat gaan vasstel of biologiese mikrobes (of andere) daar bestaan (Chown 1995:7). 'n Nuwe biologiese wetenskap, exobiologie (met biologiese lewe buite die aarde as objekgebied), bestaan ook reeds.

\subsection{Die divergensie-hipotese}

Ondanks hierdie verwikkeling is daar enkele wetenskaplikes wat meen dat rasionele lewe buite die aarde nie kon ontstaan het nie - selfs nie biologiese lewe nie. Hulle steun die divergensie-hipotese. Hierdie hipotese se grondveronderstelling is die evolusie-teorie. Hiervolgens is die hoeveelheid toevallighede van mengende en muterende genes so groot dat dit net tot divergensie kon lei. Omgewing en seleksie werk hier deterministies. Verder is evolusie eenmalig: dit is onomkeerbaar en onherhaalbaar. Synde kousaal-deterministies, sê natuurlike seleksie dat daar geen onafwendbare progressiewe vooruitgang moontlik is van ' $n$ gevinde vis na ' $n$ vierbenige aardse dier en uiteindelik na 'n tweebenige mens nie. Op aarde was evolusie 'n deurmekaar, toevallige, eienaardige en stamperige aangeleentheid. As evolusie daarom weer van vooraf op aarde sou begin sou daar geen skepsel wees wat dieselfde gestalte sal hê soos tans of in die verlede nie. Daar is geen noodwendige reguit deterministiese lyn vanaf die oorsprong van lewe na die rasionele mens nie. Op elke vlak van hierdie lyn was daar baie vertakkende punte en aparte filetiese lyne, met slegs 'n enkele een daarvan wat die voorgeslag se afkoms gevorm het en wat uiteindelik tot die ontstaan van die mens aanleiding gegee het. Natuurlike seleksie is veel eerder soos 'n gediversifiseerde voorrade-portefeulje: dit voorsien diversiteit om lewe se kanse te verbeter teen die onvoorspelbare kontingensies van 'n omslagtige sorgelose omgewing (kyk Pine 1989; Mayr 1982; Simpson 1983; Beck 1987). Rasionele lewe buite die aarde, volgens die divergensie denke, is slegs 'n vooroordeel van fisici: 
It is interesting and rather characteristic that almost all the promotors of the thesis of extraterrestrial intelligence are physical scientists. They are joined by a number of molecular and microbial biologists and by a handful of romantic organismic biologists.

Why are those biologists, who have the greatest expertise on evolutionary probabilities, so almost unanimously sceptical of the probability of extraterrestrial intelligence? It seems to me that it is to a large extent due to the tendency of physical scientists to think deterministically, while organismic biologists know how opportunistic and unpredictable evolution is .... Everybody knows of course, that determinism is no longer the fashion in modern physics and yet in conversation with physical scientists, I have discovered again and again how strongly they still think along deterministic lines'.

(Mayr 1987:24, 25)

Divergensie en die te lang vereiste tyd, maak lewe elders dus onmoontlik. Ons menslike manier van wêreld-ontmoeting is 'n divergente eienskap van evolusie.

Mayr se argument lewer egter talle probleme op. 'n Deterministiese veronderstelling is nie ' $n$ noodwendige logiese vereiste vir argumentering ten gunste van die ontstaan van rasionele lewe nie. Die kwantum-teorie met sy indeterminisme maak juis die teenoorgestelde gevolgtrekking as dié van Mayr meer moontlik. Mayr verbind verder deskundigheid met 'n bepáálde biologiese standpunt. Sy siening oor die 'eenparige skeptisisme' asook oor ander fisici is hoogs beredeneerbaar.

\subsection{Die konvergensie-hipotese}

Soos in die geval van die divergensie-hipotese geld ook hier die evolusie-teorie as veronderstelling. Die konklusie is egter lynreg die teenoorgestelde van wat gededuseer word. Hiervolgens sal soortgelykte omgewings neig om van tyd tot tyd konvergensie voort te bring: die omgewing neig om daardie lewensvorme wat die beste aangepas is te selekteer. Daarom giet dit lewe in soortgelyke kanale - gegewe soortgelyke omgewings en optimum lewenswyses binne hierdie omgewings. So sal rasionaliteit meer waarskynlik 'n konvergente eienskap as 'n divergente eienskap wees. Evolusie neig om homself in breë trekke te herhaal en die beste oorlewings-strategie te herhaal. Rasionaliteit is juis in 'n sekere sin 'n hoogs 'aanpasbare kenmerk'. Dit is dus baie aanneemlik dat dit weer sou gebeur onder dieselfde of soortgelyke omstandighede. 
Verder geld natuurwette oraloor in die heelal en hul sal dus 'n determinant (nie determinisme!) wees in soorteglyke omgewings elders in die heelal. Dus - gegewe astronomiese kanse - is dit moontlik dat skepsels meer as eenkeer sal evolueer in samehang met hierdie wette. Goeie konkrete voorbeelde hiervan is die volgende:

* Vlerke het verskeie kere op verskillende tye, onafhanklik van mekaar by verskillende spesies soos insekte, reptiele (pterodaktiele), voëls en vlermuise, ontwikkel. Om te kan vlieg is 'n ooglopende oorlewingseienskap: 'North American tourists visiting Hawaii are often surprised to find what they think are North American hummingbirds living on these tropical islands. What they are seeing however, is not a bird at all but an insect, the hummingbird moth. It looks and acts very much like a hummingbird. The moth and the hummingbird obviously have no recent common ancestor but their bodv structure and way of life have converged' (Pine 1989:265).

* Insgelyks het baie wesens visagtige liggame ontwikkel, soos die haai, en onafhanklik daarvan die dolfyn (wat eers ' $n$ landdier was). . Daar is groot verskille tussen die dolfyn en haai, maar altwee het basies dieselfde vorm omdat dit die beste vorm of gestalte is om vinnig te kan swem en kos in waterige media te vang: 'The ichthyosaurus, an extinct reptile, was an even more striking example. It looked and probably acted very much like a modern dolphin - breathing with lungs and giving birth to live young. But the ichttosaurus evolved from a lizardlike creature, whereas a dolphin envolved from a doglike land creature' (Pine 1989:265).

* Dieselfde geld met roofdiere op land: wolfagtige, katagtige en hondagtige vorme ontwikkel verskillende kere tot heel onverwante wesens. So het die swaardtand tier verskeie kere ontstaan. In Kalifornië was die oerdier 'n plasentale soogdier en in Suid-Amerika, tydens ongeveer dieselfde geologiese tyd, was daar 'n buideldier weergawe van die swaardtand tier. Dus het verassende soortgelyke anatomië onafhanklik van mekaar ontwikkel. Hoewel plasentale buidelsoogdiere 'n veraf gemeenskaplike voorgeslag het in die mesozoïese era, was hulle geneties apart vir tien miljoen jaar voordat dit verskyn het (Raup 1987:34; Pine 1989:265).

* Die oog het konvergent ontwikkel wanneer dit ookal nodig was. Oë het tewens 40 keer onafhanklik van mekaar in verskillende diere tipes ontstaan! (Salvini-Plawen \& Mayr:1987). 'n Hoogs gekomplisserde orgaan kan derhalwe onafhanklik van mekaar evolueer as dit voordelig is. Nie net het die konvergensie-argument sterker premisses as die divergensie argument nie, maar geniet dit vandag meer rugsteun onder bioloë. 
Ons wil reeds konkludeer dat daar in terme van konvergensie sterk gronde is om lewe met selfs herhaalbare ooreenkomste ten opsigte van struktuur en gedrag, ook op ander planete te verwag gegewe dieselfde omgewing. Natuurlik sal daar ook verskille wees omdat daar andersins te veel omstandighede sou moes wees wat herhaal moet word. Omdat natuurwette dieselfde is, sal in terme van seleksie sekere oplossings optimaal wees. Evolusie is in staat om dieselfde spel te speel met 'n verskillende rolverdeling van spelers (Pine 1989:266). Russell (kyk Raup 1987:42) het met rekenaarsimulering uitgewerk hoe dinosourusse, spesifiek die stenonymphosaurus, sou gelyk het as hulle nie uitgesterf het nie ( 65 miljoen jaar gelede). Hy het uitgekom by 'n mensagtige (humanoid) figuur!

Die argument is dat rasionaliteit eweneens konvergent sou kon ontwikkel. Tewens 'n nuwe hipotese in die paleobiologie toon dat die vroegste mens of mensagtiges nie noodwendig op een enkele plek in Afrika nie, maar onafhanklik van mekaar op verskillende kontinente op verskillende plekke ontstaan het. Die Afrika-hipotese geniet egter al hoe sterker steun vanweë verdere ontdekkings spesifiek in Afrika. Die voorstanders van die Afrika-hipotese sluit egter nie die moontlikheid uit van genoemde nuwe hipotese nie. Logies staan die twee hipoteses nie in 'n eksklusiewe of sterk disjunksie relasie tot mekaar nie. Dit is baie waarskynlik dat rasionele lewensvorme (en selfs mensagtiges) op soortgelyke wyse elders in die heelal talle kere kon ontstaan het. Raup (1987:40) meen dat talle lewensvorme sonder rasionaliteit elders net so kon ontstaan het, byvoorbeeld wesens met sonar stelsels (vlermuise) en elektriese stelsels (palings).

Dit moet toegegee word dat 'n principium petititio (sirkelargument) in 'n sekere sin vervat is in die gevolgtrekking van rasionaliteit as 'n optimale en hoogste eienskap van evolusie by konvergensie. Die feit dat ons self die vermoë het om te dink en te redeneer bring ons daartoe om te konkludeer dat denke en rasionaliteit 'n hoogste en positiewe eienskap is (Pine 1989:266). Dit beteken dat die premisse 'ons is immers rasioneel' en die gevoltrekking 'rasionaliteit is die hoogste eienskap' 'n petitio is. Ons ontmoet die wêreld rasioneel wetenskaplik, maar daar kort 'n verdere premisse as wetenskaplike evidensie vir die siening dat wetenskap juis 'n voorkeur-ontmoeting is om so 'n petitio te ontsnap.

Tog is dit nie 'n bose sirkel nie. Die konklusie is nie heeltemal identies met die premisse nie. Terugwaarts gesien sou die probleemoplossende werkswyse van rasionaliteit gesien kan word as 'meer' en 'anders' as wat was.

Tewens die feit dat ons rasioneel kan dink oor rasionaliteit, is per definisie 'n voorwaartse eienskap omdat dit dui op transendensie en distansiering wat by 'n geslote kultuur soos bye of miere afwesig is. Marvin Minsky van die Massachetts Instituut van Tegnologie (MIT) toon byvoorbeeld oortuigend aan waarom objekte van rasionaliteit en sekere aspekte van rasionele denke universeel in die heelal moet wees. 


\section{4. 'N BASIESE NOODSAAKLIKE VOORWAARDE VIR RASIONELE LEWE ELDERS}

Ons argumentering tot sover bring ons by die gevolgtrekking met die premisses van:

* Die universaliteit van chemiese en biologiese molekules en daarmee die teenwoordigheid van die boustene van lewe;

* sterk rugsteun vir buite-aardse oorsprong van sekere primitiewe biologiese lewe; en

* die sterk gronde en wetenskaplike rugsteun van die konvergensie-argument - dat biologiese en rasionele lewe elders in die heelal 'n baie sterk moontlikheid is.

Ons kan konkludeer dat daar grootliks voldoen is aan die noodsaaklike voorwaardes (behalwe een). Noodsaaklike voorwaardes is egter nog nie 'n genoegsame voorwaarde nie! Om te sê dat dit ' $\mathrm{n}$ uiters sterk moontlikheid is, of dat die nie-bestaan van biologiese rasionele lewe uiters onwaarskynlik is, is nog nie eksplisiete getuienis dat dit wel bestaan nie! 'n Genoegsame voorwaarde sal eers vervul wees indien beslissende getuienis gevind kan word of as die getuienis sigself bekend maak of albei. Hierby kom ons later. Tog is daar nog een laaste, maar die heel belangrikste en noodsaaklike voorwaarde waarvan al die ander noodsaaklike voorwaardes afhanklik is: biologieserasionele lewe elders mag ' $n$ baie sterk moontlikheid wees, maar as daar nie planetêre tuistes soos die aarde bestaan nie, is dit buite die kwessie. Dit is inderdaad waar die probleem lê. Daar is geen getuienis vir die bestaan van ander sonnestelsels met planete soos ons sonnestelsel nie, omdat ons vanweë die geweldige afstande en die lig van die sonne, asook tegnologiese onvermoë, nie moontlike planete buite ons sonnestelsel kon waarneem nie. Dit het alleen in spekulasie of wetenskapsfiksie verhale bestaan - nee, beter gesê: daar was tot onlangs geen getuienis nie. Baie resente bevindings en bevestigde ontdekkings het ons weg van wetenskapsfiksie by algehele realiteit laat uit kom.

Nuwe infrarooi beelde van 'n skyf van 'stof'-partikels wat die son (ster) Beta Pictoris omring, het ' $\mathrm{n}$ basis gebied vir indirekte getuienis vir planete. Planete se aantrekkingskrag versteur hul omgewings in ons eie sonnestelsel. Sou laasgenoemde analogies bevestig kan word by Beta Pictoris, dan dui dit ook dáár op die teenwoordigheid van planete Dit is juis wat die infrarooi beelde by die binne-area van die skyf aantoon (Telesco 1994). In die 23 Junie 1994 uitgawe van Nature, stel die sterrekundiges Langage \& Pantin (1994:628) hulle ontdekking hieromtrent so: 'We find that the dust 
is assymetrically distributed and is clearly depleted within $40 \mathrm{AU}$ of the star, which we interpret as indicating the possible presence of at least one planetary body orbiting $B$ Pictoris'.

In die Desember uitgawe van Nature voeg Levinson, Duncan en Wetherill die volgende bevinding ook by ten opsigte van Beta Pictoris:

One unexplained aspect of these events is the large assymetry between red-shifted and blue-shifted feautures: $90 \%$ of the events are red-shifted. We show here that such an assymetry is a natural consequence of the influence on cometary orbits of secular-resonances associated with some planetary system. Note that a secular resonance require the procession of planetary orbits, which means that there must be at least two planets in the system.

(Levinson, Duncan \& Wetherill 1994:442, 443)

Die Infrarooi Sterrekunde Satellict het hierbenewens ook vergelykbare aanduidings by die son Vega gevind. Die grootste deurbraak en direkte getuienis is dié van prof A Wolszcan van Penn-sylvania State University en sy span wetenskaplikes. Hy het vasgestel dat die Pulsar-son PSRB $1257+12$ ongetwyfeld planete het. Hy het twee planete geïdentifiseer wat albei 'n massa twee keer die van die aarde het. Verder het hy 'n maanagtige derde planeet ontdek. 'n Vierde planeet ag hy ook moontlik, maar dit is nog nie bevestig nie. Die Pulsar-son, PSRB $1257+12$ is 1,200 ligjare van die aarde verwyder.

In Oktober 1995 ontdek sterrekundiges, M Mayor en D Queloz van die Genèvesterrewag (Switzerland), 'n planeet so groot soos Jupiter wat wentel rondom die son 51 Pegasi. Hierna het die Amerikaanse astrofisici, G Marcy van die Universiteit van San Francisco en P Butler van die Universiteit van Kalifornië, die Switserse ontdekking getoets en bevestig. Marcy en Butler ontdek egter self in Januarie 1996 'n planeet met agt keer die massa van Jupiter wat 'n wentelbaan van eenhonderd en sestien dae voltooi rondom die son 70 Virgo. Terselfdertyd ontdek hulle ook 'n planeet met 'n massa drie keer dié van Jupiter wat 'n wentelbaan rondom die son 47 Ursa Majoris voltooi in eenduisend eenhonderd dae. Waar die eerste planeet te warm is, maak die oppervlakte en atmosfeer van laasgenoemde twee planete die vorming van vloeibare water en lewe heelwaarskynlik baie mootlik. Volgens Marcy beskik die planeet van 47 Ursa Majoris reën sowel as oseane. Sonnestelsels buite die aarde bestaan realiter dus wel. 


\section{KONKLUSIE}

Ons argumentering loop uit op die konklusie dat aan twee noodsaaklike voorwaardes vir buite-aardse rasionaliteit inderdaad voldoen word, naamlik:

* die bestaan van boustene van biologiese lewe elders in die heelal, en

* die bestaan van ander sonnestelsels.

Die ontologiese posisie van VVV kan dus nie sonder meer gereduseer word tot die heersende godsdienstig-kulturele situasie in Europa nie. Die konvergensie-argument se oortuigingswaarde is baie sterk. Sou ons dit alles aan die orde stel, dan sou die soeke na genoegsame voorwaardes sinvol en logies wees. Dit hou weer die konklusie in dat buite-aardse rasionele bestaanswyses nie meer op die vlak van fantasie bestaan nie, maar inderdaad reeds ' $n$ uitdaging vir filosofie en teologie konstitueer. Laasgenoemde sal in 'n volgende artikel, 'Genoegsame voorwaardes vir buite-aardse rasionaliteit: Filosofiese en teologiese oorwegings', ondersoek word.

\section{Endnote}

1 Outeur verkies die term rasionaliteit bo intelligensie, omdat intelligensie 'n wyse van aanwending van rasionaliteit is. Rasioneel dui op die vermoë om te dink, distansieëring van jou wêreld en jouself, die moontlikheid om sake te onderskei, op te weeg, te oordeel, probleme op te los, sitematies-logies te kan redeneer, die nuwe daar te stel, die wêreld te verander, vryheid, kiesvermoë en kreatiwiteit.

2 Vandag blyk dit dat daar wel reguitlynige watervore, naamlik groot riviere (maar droog), voor kom op Mars. Water het met 'uitbarstings' uit die grond in die verlede by tye sterk geloop. Kon dit nie tydens Schiaparelli kortstondig plaasgevind het nie?

3 Titan se atmosfeer is baie dieselfde as die van die aarde, maar met 'n temperatuur van $-178^{\circ} \mathrm{C}$. Op die oppervlakte is daar oseane met vloeibare koolwaterstof, en 'n kontinent so groot soos Australië.

\section{Literatuurverwysings}

Aldhous, P 1995. New ingredient for the primeval soup. New Scientist, 25 February. Baggot, J 1994. New light on the cold chemistry of space. New Scientist, 1 October. Beck, L W 1987. Extraterrestrial intelligent life, in Regis, E (ed), Extraterrestrials: Science and alien intelligence, 3-18. Cambridge: Cambridge University Press. Caproro, I 1995. Die Britte ervaar terdeë ' $n$ identiteitskrisis. Beeld, 12 Desember. Chown, M 1995. The ultimate message in a bottle. New Scientist, 18 February. Hoyle, F \& Wickramasinghe, C 1993. Our place in the cosmos: The unfinished revolution. London: Dent. 
Lagage, P O \& Pantin, E 1994. Dust depletion in the inner disk of Pictoris as a possible indicator of planets. Nature 369, 628-630.

Levison, H F, Duncan, M T \& Wetherill, G W 1994. Secular resonances and cometary orbits in the Pictoris system. Nature 372, 441-443.

Mayr, E 1987. The probability of extraterrestrial life in Regis 1987:23-30.

Pine, R 1989. Darwin's universe revisited: Intelligence, communication, and extraterrestrial life, in Science and its human prospect. Belmont (CA): Wadsworth.

Raup, D M 1987. ETI without intelligence, in Regis 1987:31-42.

Regis, J R E 1987. Estraterrestrials: Science and alien intelligence. Cambridge: Cambridge University Press.

Salvini-Plawen, L \& Mayr, E 1977. On the evolution of photoreceptors and eyes. Evolutionary Biology 10, 207-263.

Telesco, C M 1 \94. Footprints in the dust. Nature 369, 610-611. 